\title{
Behind the Stage: The Global Dimension of the Negotiations
}

\author{
Lucien Bély
}

Study of the diplomatic correspondence before the Peace of Utrecht reveals that commercial and colonial interests became very important at that time. The question of the Indies, that is, of Spanish America, may be counted as one the causes of the War of the Spanish Succession. So European diplomats had to understand and discuss such matters, but most of the negotiators, gentlemen or clergymen, were unfamiliar with these issues. Merchants could intervene in the discussions as experts and sometimes as negotiators as did, for instance, the French merchant and diplomat Nicolas Mesnager, deputy of Rouen for the council of commerce. Such interventions often formed the most secret part of the negotiations.

We can note a dialectical phenomenon. The merchants wanted to discover new markets, and the European economies needed them in a time of general crisis. On the other hand, governments and diplomats integrated those views into their demands and tried to imagine new ways to intervene throughout the world and to open new roads for commerce.

Of course, the dynastic situation was the main affair in the War of the Spanish Succession. The House of Bourbon was seeking a new relationship between the Court of Versailles and the Court of Madrid that would create a real union between them. The young Philip V, Louis XIV's grand-son, was expected to follow the king of France's political line. On the other side, the allies-Great Britain, the United Provinces and the emperor-could not accept this new European organization with such a huge aggregation of crowns in the hands of one family. This super-power would pose a threat to the stability of all of Europe. The war's military operations were the main concern of the European princes: they were waiting for the result of their strategic choices. For thirteen years, the battles dominated European history. But some other interests, particularly commercial ones, soon became factors in the negotiations among allies or between enemies as the hidden part of the conflict. 


\section{The Negotiations between France and Spain}

One of the key issues in international relations of the time involved the participation of foreigners in Spanish-American trade, despite Spain's colonial monopoly. European merchants brought to Spain the products needed for this trade, but the trade remained in Spanish hands, was controlled by Spanish officers and protected by the Spanish fleet. A 1686 investigation by the French consul Patoulet showed the place of each country in the trade of Cadiz: France ranked first; Genoa, the United Provinces, England, Hamburg, and the Spanish Netherlands each had a good share while Spain provided only $6 \%$ of the goods. ${ }^{1}$

We know that the arrival of precious metals also had important consequences for European economies. The study, in particular, of the place of precious metals and of metallic coinage in the development of Europe has been controversial for historians and perhaps for economists. The 'crisis' of the seventeenth century was described by Earl J. Hamilton, ${ }^{2}$ reinterpreted by P. Chaunu ${ }^{3}$ and discussed by Michel Morineau. ${ }^{4}$ During the War of the Spanish Succession, Mesnager wrote that New World treasure was almost the sole source of the wealth of Europe. ${ }^{5}$ And in 1710 , he wrote: 'Spanish America has

1 The foreigners themselves were present in the Spanish ports, as the Flemish in Cadiz: Jan Everaert, De internationale en koloniale Handel der Vlaamse Firma's te Cadiz (1670-1700) (Bruges: De Tempel, 1973); or the Irish present in the Canary Islands: Agustin Guimerá Ravina and José Miguel Delgado Barrado, 'Proyectismo camario y comercio americano: un plan de compañía privilegiada (1753),' El Comercio en el Antiguo Régimen, ed. Manuel Lobo Cabrera and Vicente Suárez Grimón (Las Palmas de Gran Canaria: Universidad de Las Palmas de Gran Canaria, 1994), 151-162.

2 Earl J. Hamilton, American Treasure and Price Revolution in Spain (1501-1650) (Cambridge (Mass.): Octagon Books, 1934); idem, War and Prices in Spain (Cambridge (Mass.): Harvard University Press, 1947).

3 Huguette and Pierre Chaunu, Séville et l'Atlantique (1504-1650). Partie statistique (Paris: Editions de l'Ecole des Hautes Etudes en Sciences Sociales, 1957-1958); Pierre Chaunu, Séville et l'Atlantique (1504-1650). Partie interprétative (Paris: Editions de l'Ecole des Hautes Etudes en Sciences Sociales, 1959-1960).

4 Michel Morineau, Incroyables gazettes et fabuleux métaux (Paris: Maison des sciences de l'homme, 1985).

5 Lucien Bély, Espions et ambassadeurs au temps de Louis XIV (Paris: Fayard, 1990), 576-595, here 582: 'Réflexions sur les moyens qui peuvent aider à déterminer les Hollandais à la paix,' Archives du Ministère des Affaires étrangères, Correspondance politique Hollande 214, fol. 105-107. See also: Lucien Bély, L'Art de la paix en Europe. Naissance de la diplomatie moderne, 
the largest sources of gold and silver in the world [...] everyone wants to have his own share.'

For English and Dutch merchants, as well as for their governments, the main danger with a French prince as king of Spain was the benefits that the French economy could reap, especially through direct access to the wealth of Spanish America. An 'asiento' or contract was signed between the Spanish administration and the French Company of the Asiento or of Guinea for providing slaves to the Spanish colonies. France in exchange would ensure the protection of the Spanish convoys. The main strategic choice of the war was thus whether to maintain the links between Spain and America when abandoning the European dominions of the Spanish king. Obviously, during the long war, the arrival of American metal was a breath of oxygen for the Bourbon camp. ${ }^{6}$

In the talks between the two countries the French ambassador Michel Amelot ${ }^{7}$ established a harmony between the French king's influence and the Spanish government. Daubenton, representing Pontchartrain and the Department of the Navy, had to defend French commercial interests. This 'agent général' had to gather information from the various French consuls in Spain. ${ }^{8}$ Nicolas Mesnager also came, as an expert, to hold talks with the Spanish authorities. However, in spite of French attempts to gain advantage, the Spanish administration, through very tough negotiations, maintained the uniqueness of the system and defended its independence. ${ }^{9}$

In a first negotiation, from December 1704 to May 1706, in Spain, Mesnager obtained a new organization of trade: only 'foreign allies to Spain' could send goods to America. But merchants did not wait for the result of the political

$X V I^{e}-X V I I I^{e}$ siècle (Paris: Presses Universitaires de France, 2007). For the next quote, see Bély, Espions, p. 587.

6 Guy Rowlands, 'The Economics of War. Tax, trade and credit in pursuit of an acceptable peace,' Peace was made here. The Treaties of Utrecht, Rastatt and Baden, 1713-1714, ed. Renger de Bruin and Maarten Brinkman (Petersberg: Michael Imhof Verlag, 2013), 34-41. See also Guy Rowlands, The financial decline of a great power. War, influence, and money in Louis XIV's France (Oxford: Oxford University Press, 2012).

7 For this ambassador, see Guillaume Hanotin's $\mathrm{PhD}$ thesis 'Au service de deux rois: l'ambassadeur Amelot de Gournay et l'union des couronnes,' Université Paris-Sorbonne, 3 December 2011. See also: L. Bély, 'La présence et l'action des ambassadeurs de France dans le gouvernement de Philippe v d'Espagne: conduite de la guerre et négociation de la paix,' L'Espagne et ses guerres, ed. Annie Molinié and Alexandra Merle (Paris: PU Paris-Sorbonne, 2004), 183-201.

8 This important, new function is the subject of current research by Sylvain Lloret.

9 E.W. Dahlgren, Les relations commerciales et maritimes entre la France et les côtes de l'Océan Pacifique, I, Le commerce de la mer du Sud jusqu'à la paix d'Utrecht (Paris: La Découvrance, 1909). 
negotiations. The importance of Malouins in the South Sea trade is obvious: they broke through the monopoly in the Spanish Empire but essentially chose to smuggle in goods to get around the control of Cadiz. ${ }^{10}$ The question posed by André Lespagnol is whether they wanted to participate in the American trade or share the American treasure. Saint-Malo traders discovered that direct trade in the South Seas (South Pacific) was technically possible and financially rewarding. In 1703 traders embarked on this adventure without considering the risk it posed to Franco-Spanish relations. The French General Controller of Finances gave them support in 1705 , even if he concealed it behind passports granted for voyages of discovery. So, the possibility of a French presence in American ports was established. ${ }^{11}$

Coming from Europe or leaving Peru, French sailors chose to stop near Concepcion: they settled in Talcahuano, a safe anchorage, well sheltered from the winds. This settlement became the main logistical base for French trade in the South Seas. They even built semi-permanent houses, with dormitories, where sailors could recover their health. ${ }^{12}$ The French also benefited from the protection of the colonial authorities, the Uztariz. Concepcion was finally a privileged locale for gathering information on the market conditions and on the changes in the politico-military situation. This French experience became a model: illegal or quasi-illegal trade combined with local settlement. This informal presence of European merchants seemed a pragmatic way to respect the Spanish organization while finding new markets in America. The Dutch and the English would try to obtain the same privileges in the negotiations.

England managed to secure more solid advantages from the War of the Spanish Succession in Portugal, imposing the commercial treaty negotiated by John Methuen. ${ }^{13}$ The rural Portuguese economy was now linked with the manufacturing English one while gold found in Brazil boosted this AngloPortuguese trade and fortified the financial situation of London. ${ }^{14}$

10 André Lespagnol, Messieurs de Saint-Malo. Une élite négociante au temps de Louis XIV (Saint-Malo: PU Rennes, 1990).

11 Worse, from 1712, Saint-Malo boats went to Cadiz to top up their cargo.

12 Due to longer and longer stays of the boats and to desertion, there arose a form of settlement of some French natives. A commissioner noted in 1714 that in Concepcion French officers had built houses as if they had to spend their entire life there. These Frenchmen behaved as 'in a conquered country', said the same observer, who deplored the excesses of youth. Frictions or quarrels broke out with the Spanish people settled in the area.

13 José Luís Cardoso, Isabel Cluny, Fernando Dores Costa et al., O Tratado de Methuen (1703): diplomacia, guerra, política e economia (Lisbon: Livros horizonte, impr., 2003).

14 Mesnager also assumed that the maritime powers had obtained assurances from the competitor of Philip v, Archduke Charles, giving them advantages in the Spanish-American trade in case of an allied victory. See about Charles of Austria, the Emperor Charles vi: 
The need for information also formed part of the negotiations between France and Spain. The manuscript of Jean de Monségur, about Mexico or New Spain, reveals that the French government, especially the State Secretary of the Navy, Jérôme de Pontchartrain, tried to glean accurate information on the American market. This traveller-informer appears as a 'soldier-diplomat-spy', in the words of Jean-Paul Duviols. ${ }^{15}$

According to his report, Spain allied and perhaps united with France, could provide the West Indies with all the goods consumed there and can do all the business with America. In fact, it was not so easy. Monségur described in detail the trade of New Spain. He showed how French ships from Saint-Malo, Martinique and other parts of France came to America. They took advantage of the fact that Mexico lacked many things at that time. The monopoly was also bypassed by trade carried out by Spaniards sailing from port to port: he mentions Havana, Maracaibo, Caracas and Cumaná. The French traveller described the system: French vessels arrived, especially from Saint-Malo and Martinique, richly loaded. They could not unload if they did not dispose of their goods at low prices to the Spanish officers who prevented them from freely selling their cargo to merchants. This is the lesson of the French presence: if individuals had no opportunities to buy from French hands, a large part of the profit (from $30 \%$ to 40 or even $50 \%$ ) went to the viceroy and his ministers. Monségur even points out the introduction of goods from England and Holland. He accumulated the most accurate data and numerical evaluations to identify the possibilities of trade in America. For example, he listed the main goods required in Mexico as iron, steel, white wax, fruit, silks, lace, woollen goods, groceries, papers, cards, hats, haberdashery and medicinal drugs.

Finally, the dynastic affair seemed increasingly immaterial, or at least less important, once the military operations had destroyed the Spanish Empire in Europe. Outside Spain, only Sicilia had remained in Philip v's hands. Barcelona and a large part of the Spanish peninsula were occupied by the Archduke Charles of Austria, son of emperor Leopold I and brother of Emperor Joseph I. So, the war aims of the House of Austria were nearly fulfilled. The commercial aspect of the war remained, however, the main concern for London and The Hague.

Virginia Sanz, Entre Austrias y Borbones: el archiduque Carlos y la monarquía de España (Madrid: Sigilo, 1993); Virginia Léon, Carlos vi: el emperador que no pudo ser rey de España (Madrid: Aguilar, 2003).

15 Mémoires du Mexique: le manuscrit de Jean de Monségur, 1707-1709, ed. Jean-Paul Duviols (Paris: Chandeigne, 2002). 
French diplomacy therefore chose to place the negotiations with its enemies on the same commercial terms. First with the Dutch who remained intransigent, then with the English who jumped at the opportunity. These negotiations required the use of specialists such as Mesnager who was instructed to put in order and form proposals on topics that diplomats usually had little mastery of.

The first secret negotiations between France and its enemies had begun in the United Provinces. ${ }^{16}$ This country appeared in the seventeenth century as a key financial and commercial centre and a place of relative religious tolerance. Negotiators sent by France could easily disguise the purpose of their travels. The French minister of foreign affairs went himself to The Hague to negotiate with Heinsius. Despite such favourable conditions, the French negotiations with the United Provinces reached an impasse. The Dutch government was not seduced by French commercial proposals and remained faithful to the Great Alliance.

\section{The Negotiations between France and England}

During the year 1711, negotiations became possible between France and England after the change of government in London and the military defeats of Brihuega and Villaviciosa in Spain. Matthew Prior, a poet and also a former secretary of the English embassy in Paris, arrived in France: he gave a precise and lively report of his negotiations with the marquis de Torcy, the French Secretary of State for foreign affairs. About commercial affairs, he quoted the words of Torcy: ' "Monsieur Prior, dit-il, vous avez été dans le commerce, reflechissez un peu sur ce memoire"; so beginning at "Pour la Great Britain plus particulièrement", he said that we asked no less than to be master of the Mediterranean and Spain, to possess ourselves of all the Indies, and to take away from France all that appartains to that crown in America. ${ }^{17}$ The discussion was about four places in America. Prior answered that Spain would have little reason to fear from [English] settlements, which were to secure [English traders] from pirates and robbers, particularly in the South sea,' who were, according to Prior, 'most Englishmen, and some French, particularly Dunkirkers'. France, a 'generous

16 Johanna Geertruida Stork-Penning, Het Grote Werk. Vredesonderhandelingen gedurende de Spaanse Successie-oorlog, 1705-1710 (Groningen: J.B. Wolters, 1958).

17 Report on the manuscripts of His Grace the Duke of Portland, preserved at Welbeck Abbey, vol. v (London: printed for Her Majesty's stationery office, 1899), 'Prior's Negotiations in France,' 35 . 
nation,' hated them as much as England did, and Spaniards would be happy to be protected 'from the violence of these buccaneers'. Torcy considered that such a settlement was impossible: it was 'a constant rule of Spain, not to let in any other nation amongst them in America'. Later, in his Mémoires, Torcy would recall Prior's words: 'Il coûtera peu au roi catholique de les [the four places] accorder à l'une et à l'autre nation dans la grande étendue des terres soumises à la monarchie d'Espagne, depuis la Californie jusqu'au détroit de Magellan.'18

Then Torcy underlined another 'impossibilité' about 'la terre neuve': '. . it is the nursery of our seamen, our fishers are obliged as yours are, to take young men to perform that voyage $[\ldots]$ and for fish we have more need of it than you, for we are indispensably obliged to consume it ourselves, while you for the greatest part propose to yourselves only the profit of selling it to others.' ${ }^{19}$ Prior knew that 'some temperament might be found in the negotiation upon this head'. He answered only that all Hudson's Bay was English, and, as a proof, he indicated 'that the names of all the banks and towns even in the French maps have always been and are now English'. For Newfoundland, the phrase 'terre neuve' came from the English name: a very interesting way to defend the priority of the settlement by maps. The idea of a 'temperament' referred to a solution already found regarding fisheries: it would be the right of French fishermen to prepare cod on the 'French shore'. Torcy met Prior on the following day. The king of France had asked 'those persons who are most versed in the mercantile affairs to consider of and report their opinion upon the proposals'.

On the 27 th of July, the meeting took place at nine in the evening in the gardens of Fontainebleau; the abbot Gaultier was with the two negotiators. Torcy evoked the Dutch gazettes which expressed surprise in the Netherlands about the South Sea Company. The French secretary of State said that French merchants were also very anxious about the South Sea Company. Prior replied that French traders could make 'what bargain they could with Spain'. The French minister swore by his 'foi d'honnête homme' that France was not on a better footing than it had been in the time of Charles II and that the Spaniards were most jealous of the French since a prince of the house of Bourbon was on the throne. This was the lesson of the Franco-Spanish negotiations.

In July 1711, Daniel Defoe sent Harley papers about a settlement in America. He wrote that some of those schemes had been approved by William III at the beginning of the war. The kingdom of Chile was suitable for an English colony,

18 Mémoires du marquis de Torcy, Collection des mémoires relatifs à l'histoire de France, ed. ? A. Petitot and Monmerqué, 2-LVIII (Paris: Foucault, 1828), 30-31. 
especially in the town of Valdivia. This paper underlined that many natives were 'hating the Spaniards and willing to receive any nation that are likely to deliver them from the slavery they are under to the cruel and tyrannic temper of the said Spaniards. ${ }^{20}$ Then came an interesting anthropological remark: 'These natives are a foundation of commerce, because they go clothed and would generally clothe themselves if they could obtain manufactures.' This colony could produce rice, cocoa and wine, and in the north, sugar and spices. Another settlement could be made between the Rio de la Plata and the straits of Magellan. Land connections could link this colony to Chile.

\section{The Negotiations between England and the United Provinces}

To understand the reaction of the Dutch, we can rely upon the letters sent by John Drummond, a banker, to Harley; this interesting commercial figure has been studied by Ragnhild Hatton. ${ }^{21}$ I want to consider the passages of his correspondence concerning world commerce.

John Drummond had conversations with the Dutch Grand Pensionary Heinsius, and he could enumerate the new conditions for a peace. It seemed difficult to drive Philip v out of Spain, but the trade with the Spanish West Indies must be secured as formerly through Spain, and France was to have no greater privileges there than other nations.

As we have seen, the South Sea Company impressed public opinion in France as well as in the United Provinces. Drummond wrote that a South Sea Company was also proposed by the Dutch 'to be exerted by way of subscription' and that was kept 'very secret'. According to Drummond, 'a part of the project is formed in Surinam, on which this Company is to act'. Some details arrived on 14 July. Amsterdam encouraged the secret project to establish a settlement on the continent of the Spanish West Indies. That city would control the financial arrangements. They demanded only six men-of-war, twelve or fifteen hundred land men 'and six hundred slaves, ready at Surinam, to be taken aboard there. They required also three hundred craftsmen (bricklayers, carpenters and smiths) and artillery for a fort. The location of the place remained secret:

20 Report on the manuscripts of His Grace the Duke of Portland, preserved at Welbeck Abbey (London, printed for Her Majesty's stationery office, v-VI, 1899), 59, Daniel Defoe to the Earl of Oxford.

21 Ragnhild Hatton, 'John Drummond in the War of the Spanish Succession. Merchant turned Diplomatic Agent,' Studies in Diplomatic History, ed. R. Hatton and M.S. Anderson (London: Longmans, 1970), 69-96. 
'The place they design is said to be in the kingdom of Mexico, but as well is yet kept extremely secret, you may be sure that part will be discovered last.'22 So, the Dutch wanted to have a South Sea Company too. Here we note the workings of a European process of imitation through the circulation of ideas and of projects. Those proposed Dutch settlements could evoke the French presence on the South Pacific coast. Because the Spanish empire seemed weaker, it is possible to imagine local or regional settlements which could be accepted by Madrid. Torcy was right to underline the resistance of the whole Spanish organization against such projects. Such enterprises involved slaves—six hundred here: they were useful instruments in those projects and were now present in the representation of America and of European ambitions.

All the pamphlet campaign, beginning with Swift's Conduct of the Allies, was meant to demonstrate that the British effort during the war was stronger than any other, ${ }^{23}$ and so it must be rewarded by some economic advantages in the world. Nothing was negotiated to reinforce the power of the country. Only trading facilities were necessary to satisfy the ambitions of the people in the British Islands. Such demands were in line with the political equilibrium obtained through the revolution of 1688 , the government following the impulse of the political nation. They also revealed the new ambitions of the Tory faction: to avoid a continental military engagement, to discard the moneyed interest and to protect the landed interest and reinforce the world empire.

The opening of the Utrecht Congress in 1712 was supposed to transform the secret discussions into public negotiations, giving lustre to the search for peace by attracting in Utrecht about eighty negotiators and a crowd of onlookers. They were actors on the stage ${ }^{24}$ as princes were on the theatre of Europe, according to a common metaphor of that time. The social activity gave them opportunities for meeting their counterparts, and their conversations were transcribed in dispatches from the negotiators, as if Congress had given them a new dignity and political weight. Thus, a congress exacerbates a specific sociability based on a common diplomatic culture. A congress

22 Report on the manuscripts of His Grace the Duke of Portland, 28, John Drummond to the Earl of Oxford, 14 July 1711.

23 Douglas Coombs, The Conduct of the Dutch, British opinion and the Dutch alliance during the War of the Spanish succession (The Hague: M. Nijhoff, 1958).

24 Lucien Bély, 'Utrecht, un théâtre pour la paix,' in Les Pays-Bas et la France des guerres de religion à la création de la République batave, ed. W. Frijhoff and O. Moorman van Kappen (Nijmegen: Gerard Noodt Instituut, 1993), 53-76, reprinted in L'Art de la paix en Europe, 503-524. 
belonged also to a certain form of communication. Even if they were sometimes considered as formalities, as an empty reality, such diplomatic assemblies accompanied a geopolitical reorganization and helped proclaim a new stability through an agreement between the belligerents. Behind the stage, there was also a world of spies, informers, journalists and chroniclers, of travellers and aristocrats, of writers, comedians and adventurers. They were all interested in this diplomatic assembly that seemed the great tribunal of political affairs in Europe. They were creating an international public opinion. ${ }^{25}$

In fact, formal negotiations soon gave way to direct talks between London, Versailles, Madrid and Turin. However, from 1712, the general congress in Utrecht covered many negotiations, especially between the allies, the United Provinces and Great Britain. A new treaty was prepared for the Barrier, and it was not as favourable as the previous one.

John Drummond had discussions with Dutch statesmen and asked Harley to procure or at least to do his utmost to obtain for the Dutch or for their West India Company the 'asiento of negroes' for the northern parts of the Spanish West Indies, namely for Carthagena and Portobello, since everybody was convinced that the English company would supply the whole South Sea coast of America. Dutch opinion needed 'some douceur of that nature'26 to accept the British gains. In the same letter, John Drummond described the way in which the mercantile interests could impress the diplomatic congress: 'The deputies of the West India Company went to Utrecht last Saturday, and from thence to the Hague with the States Plenipotentiaries, and by what I can learn, Porto Rico, a small and almost uninhabited island on the north coast of America, for the security of the Curacao trade, and the furnishing of negroes to the north side of the Spanish West Indies, is what they are resolved to insist on, and that they are to come as an equivalent to what they suppose you have obtained for your South Sea Company ...27 The deputies of the Dutch company came to press the diplomatic delegations hard. Four days later, John Drummond wrote to Harley after two long conferences with Heinsius: '... he is for making the peace jointly with England, but assures me that your Lordship must help him, both as to the barrier treaty and some condescension in the negro trade in favour of the Dutch West India Company, for it is impossible for him to satisfy men's minds here till he can obtain something by which he can show them

\footnotetext{
25 Lucien Bély, 'Peut-on parler d'une opinion publique internationale à l'époque moderne ?,' L'Opinion publique en Europe (160o-180o) (Paris: PU Paris-Sorbonne, 2011), 161-181.

26 Report, op. cit., 158, John Drummond to the Earl of Oxford, 15 April 1712.

27 Report, op. cit., 159, John Drummond to the Earl of Oxford, 15 April 1712.
} 
that England has not been working altogether a separate interest. ${ }^{28}$ We must remember that war was going on in America. In 1711, Duguay-Trouin had taken Rio de Janeiro. In 1712, Cassard managed to ransack Capo Verde, Montserrat and Antigua, and later Surinam and Curacao.

France also had new ambitions, especially for Louisiana. John Drummond wrote: 'This new patent of the French King's to Mons. Crossat [Crozat] for the trade of New Mexico; of which Renard has sent your Lordship a copy, gives muche jealousy and I am extremely out in my weak politics if this be well timed of the French Court to give out such a patent now.'29 Those lettres patentes presented, through the 14th article, the new importance of the slave trade: 'Si pour les cultures et plantations que ledit Crozat voudra faire faire, il juge à propos d'avoir des nègres audit pays de la Louisiane, il pourra envoyer un vaisseau tous les ans, les traiter directement à la côte de Guinée, en prenant par lui permission de la Compagnie de Guinée de le faire, il pourra vendre ces nègres aux habitants de la colonie de la Louisiane, et faisons défense à toute compagnie et autre personne que ce soit, sous quelque prétexte que ce puisse être, d'en introduire ni d'en faire commerce dans ledit pays, et dudit sieur Crozat d'en porter ailleurs. ${ }^{30}$ The diplomatic negotiations showed how world geography could be used in political discussions and how commercial projects are defined and prepared: an alliance of pragmatism and imagination nourished by the culture of the time.

The end of a long war brought good news. For the populations it meant the end of difficult times: fiscal pressure, military mobilization, ideological struggle, political tensions. There were great celebrations with fireworks to express the public rejoicing. Nevertheless, the peace treaties appeared finally as a failure for most of the countries involved in the war. The Dutch found no reward for their efforts. English opinion was mobilized against the commercial treaty, ${ }^{31}$ and Parliament rejected it. For George I, who became king in 1714, the agreement with France was shameful, and the negotiators had to defend themselves or to escape to the continent. For France, the loss of a part of Canada and of Newfoundland had heavy consequences. Spain had lost its European Empire and must struggle to neutralize English ambitions in America. The emperor would not renounce his claim to Spain. Perhaps, only the duke of

\footnotetext{
28 Ibidem, 162, John Drummond to the Earl of Oxford, 19 April 1712.

29 Ibidem, p. 236, John Drummond to the Earl of Oxford, 25 October 1712.

30 Lettres patentes du roi, Fontainebleau, 15 septembre 1712, source Gallica.bnf.fr.

31 Eric Schnakenbourg, 'Les interactions entre commerce et diplomatie au début du XviII ${ }^{\mathrm{e}}$ siècle: l'exemple du traité de commerce franco-anglais de 1713,' Histoire, Economie et Société 3 (2004): 349-365.
} 
Savoy, now king of Sicily, and the king of Prussia could be satisfied with the new geopolitical order.

The advantages obtained by the British government were probably chimerical dreams, as were those usually created by the Spanish-American trade. The 'navio de permiso' had little importance: it actually meant the consolidation of trade routes in the margin of the Carrera de Indias. ${ }^{32}$ The contract for the slave trade led to a financial collapse of the South Sea Company in England. ${ }^{33}$

Two facts remained, nonetheless: English smuggling in the Spanish empire expanded, resulting in permanent tensions of which the War of Jenkins' Ear was the clearest evidence. The second basic fact was the decisive economic importance of the slave trade. Mesnager had recognized the importance of this trade for the coasts of Senegal, and trade could be carried out from the Guinean coast to the Cape of Good Hope to the profit of the State. While selling goods of little value, it was possible to buy gold, ivory, wax, gum and leather, and he added: 'Ce commerce nous fournit encore des nègres que l'on transporte à Cayenne, Saint-Domingue et aux îles sans lesquels on ne pourrait les cultiver.' ${ }^{34}$ The attribution of the asiento to a British company did not prevent the Atlantic French ports from taking advantage of this human trade. And the whole European economy benefited from the products supplied by the colonial islands and redistributed throughout Europe.

Agreements in conjunction with the Peace of Utrecht also revealed the historical evolution of trafficking. However, the planned activity of companies or chartered privileges were never fully implemented; they did not realize their contract or project. ${ }^{35}$ Consequently only the liberalization and privatization of the slave trade led to the prosperity of the eighteenth century. Again, freedom from state control was favourable to slave trafficking and also to worldwide trade.

In any case, diplomatic discourse, an expression of political power, recognized the incalculable benefit of trafficking. Diplomacy succeeded in organizing a new agreement between Spain and English merchants who replaced the French ones. The political culture of the time was now aware of the mercantile

32 Antonio García-Baquero González, La Carrera de Indias. Histoire du commerce hispanoaméricain (XVI ${ }^{e}-X V I I I^{e}$ siècles), transl. B. Bennassar, (Paris: Desjonquères, 1997). Helen J. Paul, The South Sea Bubble. An Economic History of its Origins and Consequences (London: Routledge, 2011).

34 Archives du Ministère des affaires étrangères (Paris-La Courneuve), Mémoires et documents France 2018 'Mémoire du sieur Mesnager,' fol. 11-115, December 1703, see Bély, Espions, $577-578$.

35 Serge Daget, La Traite des Noirs, (Rennes: Ouest-France Université, 1990). 
interests and of the importance of the slave trade, ${ }^{36}$ which generated a circuit invisible to the European populations, allowing them to forget about the barbaric aspects of this trade.

The treaties of Utrecht, Rastatt and Baden brought an end to the war and the negotiations in 1713-1714. The new political map of Europe was approved. The congress showed that all the countries involved in the war would accept this new order. It would open a new era of peace, and peaceful discourse would replace ideological mobilization. On the stage, many diplomats played their part and defended the interests of their masters. A general discussion was possible in this diplomatic framework. Some issues were not dealt with: the future of French Protestant refugees, the case of the Catalans, who were treated by Philip v as enemies and rebels, ${ }^{37}$ the future of the Jacobites and of the Stuart prince expelled from France, the problem of the Hungarian prince Rákóczi, now incognito in Paris. ${ }^{38}$

The conduct of the English government, especially Bolingbroke's dramaturgical sense, placed England at the centre of European affairs. British diplomacy created a new balance of power on the continent. The commercial affairs and the global dimensions of the war were the basis of this peace but had been discussed quite discreetly. The shameful commerce of slaves had remained behind the stage. Why? Because of Christian remorse? Perhaps. Or because such affairs did not belong to the sphere of official diplomacy. So, diplomats succeeded in hiding this part of the negotiations which were considered as private business. Commercial affairs were, however, one of the foundations, too often neglected, of the Peace of Utrecht.

36 Henri Sée and L. Vignols, 'L'envers de la diplomatie officielle de 1715 à 1730,' Revue belge de philologie et d'histoire 5:2-3 (1926), 471-491.

37 Joaquim Albareda, La Guerra de successió i l'onze de setembre (Barcelona: Editorial Empúries, 200o); idem, Felipe vy el triunfo del absolutismo. Cataluña en un conflicto europeo (1700-1714) (Barcelona: Generalitat de Catalunya, 2002); idem, El 'cas dels Catalans.' La conducta dels aliats arran de la guerra de successió (1705-1742) (Barcelona: Fundació Noguera, 2005); idem, La Guerra de Sucesión en España (1700-1714) (Barcelona: Editorial Crítica, 2010).

38 Linda Frey and Marsha Frey, Societies in upheaval. Insurrections in France, Hungary, and Spain in the early eighteenth century (New York, London: Greenwood Press, 1987). 